Learning to Forget 



\section{Learning to Forget}

US ARMY COUNTERINSURGENCY DOCTRINE AND PRACTICE FROM VIETNAM TO IRAQ

David Fitzgerald 
Stanford University Press

Stanford, California

() 2013 by the Board of Trustees of the Leland Stanford Junior University.

All rights reserved.

No part of this book may be reproduced or transmitted in any form or by any means, electronic or mechanical, including photocopying and recording, or in any information storage or retrieval system without the prior written permission of Stanford University Press.

Special discounts for bulk quantities of Stanford Security Studies are available to corporations, professional associations, and other organizations. For details and discount information, contact the special sales department of Stanford University Press.

Tel: (650) 736-1782, Fax: (650) 736-1784

Printed in the United States of America on acid-free, archival-quality paper

Library of Congress Cataloging-in-Publication Data

Learning to forget : US Army counterinsurgency doctrine and practice from Vietnam to Iraq / David Fitzgerald.

pages $\mathrm{cm}$

Includes bibliographical references and index.

ISBN 978-0-8047-8581-5 (cloth : alk. paper)

1. Counterinsurgency-United States-History. 2. United States. Army-History.

3. Vietnam War, 1961-1975-United States. 4. Vietnam War, 1961-1975-Influence.

5. Iraq War, 2003-2011. I. Title.

U241.F5 2013

355.02'18097309045-dc23

2012043943

Typeset by Thompson Type in 10/14 Minion 
For Sarah 
